Cite: Kyei, K. A., \& Ramuya, R. S. (2021). Determination of the Level and Trend of Fertility in Four Provinces in South Africa. Demohrafiia ta sotsialna ekonomika - Demography and Social Economy, 3 (45), 41-52.

https://doi.org/10.15407/dse2021.03.041

УДК 311.17.

JEL Codes: J10, J11, J13

K. A. KYEI, PhD (Faculty member, former Chair of Statistics)

Department of Statistics of the University of Venda

Private Bag X5050, Thohoyandou, 0950, Limpopo province, South Africa

E-mail: Kyei61@gmail.com; Kwabena.Kyei@univen.ac.za

ORCID: 0000-0003-1630-3906

R. S. RAMUYA, PhD Candidate in Statistics (Graduate Assistant)

Department of Statistics of the University of Venda

Private Bag X5050, Thohoyandou, 0950, Limpopo province, South Africa

E-mail: Ramuyarotondwa@gmail.com

ORCID: 0000-0003-4404-2264

\title{
DETERMINATION OF THE LEVEL AND TREND OF FERTILITY IN FOUR PROVINCES IN SOUTH AFRICA
}

Relevance of the research: The study of fertility and mortality is of great importance because it shows the dynamics of the population and the need for effective planning measures required to be put in place to avert catastrophe. It is therefore important for South Africa also to check whether its fertility is heading toward the same trajectory seen in these developed countries. Purpose of the article: This study seeks to determine the level and trend of the fertility in South Africa using four provinces, Mpumalanga, Kwazulu-Natal, North West and Limpopo, for the years 2011, 2012, 2013 and 2014, as case studies. Thus, the study aims to determine: (a) Whether the fertility rate was changing in the provinces during the years 2011, 2012, 2013 and 2014. (b) What is the trend? And; (c) Whether the fertility is falling below replacement level or not. Scientific novelty of the article: The study shows that fertility in South Africa has indeed declined with some provinces having the level of fertility below replacement level. The decline seen in this study is mainly due to the fertility of the black majority population. The high population growth rate was mainly due to the fertility of the blacks, therefore, when recent fertility levels in the country are low, the implication is that the fertility of the blacks has gone down, and in fact this is what this study is showing, and advises that unless measures are put in place, the fertility of the blacks or fertility in South Africa will go down below replacement level.

Fertility levels have declined worldwide, including South Africa. But the extent to which South Africa's fertility has declined is not very clear because data from two previous censuses on fertility and mortality were very poor. South Africa (SA) had reliable data on the White popula- 
tion of the country, but with the new dispensation since 1994, data collection, especially from the black population that forms majority, has not been easy. The quality of data from the black population that accounts for over 80 percent of the population has not been good and reliable, probably because of the low level of education of this segment. Fertility and mortality data from the two previous censuses, 2001 and 2011, were not reliable when compared with data from vital statistics and national population register. Thus, estimates made from these censuses' data on these events are questionable. South Africa, however, has data from the General Household Surveys (GHS), and this study uses data from these surveys to attempt to find the level and trend of fertility. The GHS is an annual household survey which measures the living circumstances of South African households. Demographic and statistical methods are used to calculate measures, like the UN age ratio scores, to assess the quality of the data from four provinces, namely, North West, Kwazulu-Natal, Mpumalanga and Limpopo provinces, for the period 2011 to 2014. The four provinces are selected as a case study to compare rural and urban fertility characters. The results show that the quality of the survey data is fairly good and reliable with KwazuluNatal province having the most reliable data. The fertility levels were lowest in the more urbanized and educated provinces of Kwazulu-Natal and North West, and highest in the less educated and rural provinces of Limpopo and Mpumalanga. The study further shows that fertility in all the provinces has been declining since 2012, with the gross reproduction rate falling below replacement level; with implication that the fertility of the black population is declining fast. The decline in the fertility level could be attributed to quite a number of factors including education, urbanization, and improvement in primary health care. Because of the sharp decline in the fertility level in the recent years, the study calls for proper policy intervention to avoid population "extinction".

Keywords: fertility, household survey, reliable, replacement level, trend

Introduction. Southern Africa has had slightly lower fertility in the past years, when compared to other regions on the continent (Assefa and Semahegn, 2016). South Africa appears to be the most developed country on the continent, and therefore could have lower fertility than most of its neighbouring countries. There are nine provinces in South Africa, but this study is centred on four of them purely for a case study purpose. The four provinces are Limpopo, Mpumalanga, Kwazulu-Natal and North West. Limpopo and Mpumalanga are based in the northern region of South Africa, where rural areas are dominant. Kwazulu-Natal is situated in the southeast part of South Africa and North West is in the west of the major population centre of the Gauteng province. According to the estimates by Moultrie and Timaeus (2002), the total fertility rates have moved from almost six children in the 1960s to about four in the 1990s. While some authors contend that the drop in fertility has been remarkably sharp (Swartz, 2002; Bhat \& Zavier, 2003; Clark, 2000), others like Caldwell and Caldwell (1993) argue that, given South Africa's state of development and the resources invested in promoting family planning in the 1980s or earlier, a steeper decline was expected.

Relevance of the research: The study of fertility and mortality is of great importance because it shows the dynamics of the population and the need for effective planning measures required to be put in place to avert a catastrophe. Many developed countries have had their fertility levels decline to below the replacement level and now have to depend on "immigrants to boost" labour mar- 
kets. It is therefore important for South Africa also to check whether its fertility is heading toward the same trajectory seen in these developed countries.

Purpose of the article: This study seeks to determine the level and trend of the fertility in South Africa using four provinces, Mpumalanga, Kwazulu-Natal, North West and Limpopo for the years 2011, 2012, 2013 and 2014, as case studies.

Thus, the study aims to determine:

(a) Whether the fertility rate was changing in the provinces during the years 2011, 2012, 2013 and 2014.

(b) What is the trend? And;

(c) Whether the fertility is falling below replacement level or not.

Scientific novelty of the article: The study shows that fertility in South Africa has indeed declined with some provinces having the level of fertility below replacement level. The decline seen in this study is mainly due to the fertility of the black majority population. In the 1960s, the fertility of the white population was already very low at replacement level. The high population growth rate was mainly due to the fertility of the blacks, therefore, when recent fertility levels in the country are low, the implication is that the fertility of the blacks has gone down, and in fact this is what this study is showing, and advises that unless measures are put in place, the fertility of the blacks or fertility in South Africa will go down below replacement level.

Analysis of recent studies and publication: As stated above, the white fertility in South Africa was already at reasonably low levels in the 1960s, therefore the decline in fertility was largely caused by a decline in African and Coloured fertility (the non-Whites) who form the majority. It is true that the mechanisms through which fertility decline comes about are difficult to unravel because different nations went through the decline through different paths; ranging from socio-economic development, provision of health and medical care and other factors including contraception and even abortion. However, it is known that fertility is higher in the countries that have a high proportion of less educated people, and is lowest in urbanized areas with a high proportion of educated people (Moutrie \& Timæus, 2002; Udjo, 2009; Chimere-Dan, 1999; Department of Health, 1998). An urbanized province with high economic activities, such as Kwazulu-Natal, has lower fertility as compared to the least urbanized province of Limpopo (Udjo, 2005). Urbanization or development could be another factor that has brought down fertility level as the rural areas of South Africa are all being developed adequately (Swartz, 2002; Bhat \& Zavier, 2003; Udjo, 2005; Kyei, 2007).

Data and methods. Secondary data have been used in this study. The data come from General Household Survey (GHS) because data from the last two South Africa's censuses of 2001 and 2011 are not reliable, there are some serious undercounts and over-counts at certain age groups when compared with vital statistics and/or data from the national population register (Statistics South 
Africa, 2012). The GHS data are from 2011, 2012, 2013 and 2014 and cover four provinces in South Africa. The choice of the four provinces was purely for case study purposes to detect whether there would be differences in fertility character due to urban-rural effects. The general household survey is undertaken annually, but at the time of our study, data from the late 2010s were not yet available, and that's the reason why we used data up to 2014.

Analysis. Applications of demographic and statistical methods have been used to do these analyses. The UN age ratio score method has been applied to check the quality of the data for the years, 2011, 2012, 2013 and 2014.

The age ratios are defined as follows:

$$
\mathrm{UN} \text { method }=\frac{200 \mathrm{P}_{\mathrm{X}}, \mathrm{X}+4}{\left(\mathrm{P}_{\mathrm{X}-5}, \mathrm{X}-1 ; \mathrm{PX}+5, \mathrm{X}+9\right)}
$$

Age-ratio gives us an assessment of vertical quality of the data. If the quality of data is good, the ratio will be almost the same (about $100 \%$ ) from one age group to another.

Age specific fertility rates (ASFR) have been calculated. ASFRs are important measures in fertility studies because the likelihood of having a child varies with age.

ASFR $=(\#$ of live births to women in specified age group in a given year / \# of women in same age group) $\times 1000$

The total fertility rate (TFR) is the average number of children that would be born alive to a woman during her lifetime if she were to pass through her childbearing years giving births according to the current schedule of age specific fertility rate.

$$
\text { TFR }=\text { sum of ASFR } \times 5=5 \sum \text { ASFR }
$$

Table 1. Summary of the Age Ratio Score by Province by year

\begin{tabular}{|c|c|c||l|c|c|}
\hline \multicolumn{1}{|c|}{ Province } & Year & $\begin{array}{c}\text { Age Ratio Score } \\
(\text { UN) }\end{array}$ & Province & Year & $\begin{array}{c}\text { Age Ratio Score } \\
\text { (UN) }\end{array}$ \\
\hline \multirow{2}{*}{ Limpopo } & 2011 & $\mathbf{6 . 6 3}$ & North West & 2011 & $\mathbf{6 . 8 2}$ \\
& 2012 & $\mathbf{6 . 7 5}$ & & 2012 & $\mathbf{6 . 1 5}$ \\
& 2013 & $\mathbf{6 . 3 1}$ & & 2013 & $\mathbf{7 . 9 6}$ \\
& 2014 & $\mathbf{5 . 6 1}$ & & 2014 & $\mathbf{5 . 4 0}$ \\
& 2011 & $\mathbf{7 . 4 4}$ & Kwazulu-Natal & 2011 & $\mathbf{3 . 7 9}$ \\
& 2012 & $\mathbf{5 . 5 8}$ & & 2012 & $\mathbf{4 . 8 6}$ \\
& 2013 & $\mathbf{4 . 8 6}$ & & 2013 & $\mathbf{3 . 3 6}$ \\
& 2014 & $\mathbf{5 . 6 4}$ & & 2014 & $\mathbf{4 . 3 6}$ \\
\hline
\end{tabular}

Source: Author using data from General Household Survey, 2011-2014. 
Total fertility and gross reproduction rates have also been calculated. Gross reproduction rate (GRR) has been considered because the index indicates the number of daughters that a mother can have during the childbearing years. It shows whether, on the average, a woman bears a daughter to replace herself or not; because if GRR is greater than one then it means a woman would have more than one daughter, therefore, the population will grow. On the other hand, if GRR is less than one, it means a woman is not replacing herself, and such scenario will lead to a population decline or decrease, or even a population extinction in the long run.

NB: Assuming that in every 203 babies born in a given period or year such that 100 are girls and 103 are boys, then GRR $=(100 / 203) \times$ TFR.

\section{Results. Determination of the quality of data: Age ratio score}

The age ratio scores show that the quality of the data was fairly good. The data quality in Kwazulu-Natal was generally of better standard than the other provinces. In 2013, for example, the age ratio score in Kwazulu-Natal was 3.36, showing that the quality was very good. The quality in 2011 was equally very good, with age ratio score at 3.79. Age ratio scores which are less than 5 signify that the data quality is good and reliable.

Fertility Level. Table 2 indicates the level of fertility by province and by year. It is clear that fertility level has evolved during the period in question. All the four provinces have seen a decline in the total fertility rates from 2012. The fertility rate in the Limpopo province moved from 2.95 in 2012 to 2.31 in 2014, a drop of $21.7 \%$; the rate declined in Mpumalanga from 2.63 in 2012 to 1.99 in 2014, a decrease of $32.2 \%$; declined in North West from 2.88 in 2012 to 1.63 in 2014, a decline of $43.5 \%$; and declined from 2.43 in 2012 to 1.89 in 2014, a drop of $22.2 \%$ in Kwazulu-Natal.

Trend analysis of fertility. Tables 3 and 6, and Figures 1-9 all show some trend analyses for fertility for the provinces from 2011 to 2014. The figures clearly show how fertility in these provinces has evolved during the period.

\section{TRENDS}

Table 2. Fertility levels by province by year

\begin{tabular}{|c|c|c|c|c|c|c|c|c|}
\hline Year & $\begin{array}{c}\text { TFR } \\
\text { KZN }\end{array}$ & $\begin{array}{c}\text { TFR } \\
\text { North } \\
\text { West }\end{array}$ & $\begin{array}{c}\text { TFR } \\
\text { Mpuma- } \\
\text { langa }\end{array}$ & $\begin{array}{c}\text { TFR } \\
\text { Limpopo }\end{array}$ & $\begin{array}{c}\text { GRR } \\
\text { KZN }\end{array}$ & $\begin{array}{c}\text { GRR } \\
\text { North } \\
\text { West }\end{array}$ & $\begin{array}{c}\text { GRR } \\
\text { Mpuma- } \\
\text { langa }\end{array}$ & $\begin{array}{c}\text { GRR } \\
\text { Limpopo }\end{array}$ \\
\hline 2011 & 2.23 & 2.77 & 2.57 & 2.86 & $\mathbf{1 . 1}$ & $\mathbf{1 . 4}$ & $\mathbf{1 . 3}$ & $\mathbf{1 . 4}$ \\
2012 & $\mathbf{2 . 4 3}$ & $\mathbf{2 . 8 8}$ & $\mathbf{2 . 6 3}$ & $\mathbf{2 . 9 5}$ & $\mathbf{1 . 2}$ & $\mathbf{1 . 4}$ & $\mathbf{1 . 3}$ & $\mathbf{1 . 5}$ \\
2013 & $\mathbf{2 . 2 3}$ & $\mathbf{1 . 9 0}$ & $\mathbf{2 . 1 5}$ & $\mathbf{2 . 5 6}$ & $\mathbf{1 . 1}$ & $\mathbf{. 9 4}$ & $\mathbf{1 . 1}$ & $\mathbf{1 . 3}$ \\
2014 & $\mathbf{1 . 8 9}$ & $\mathbf{1 . 6 3}$ & $\mathbf{1 . 9 9}$ & $\mathbf{2 . 3 1}$ & $\mathbf{. 9 3}$ & $\mathbf{. 8 0}$ & $\mathbf{. 9 8}$ & $\mathbf{1 . 1}$ \\
\hline
\end{tabular}

Source: Author using data from General Household Survey, 2011-2014. 


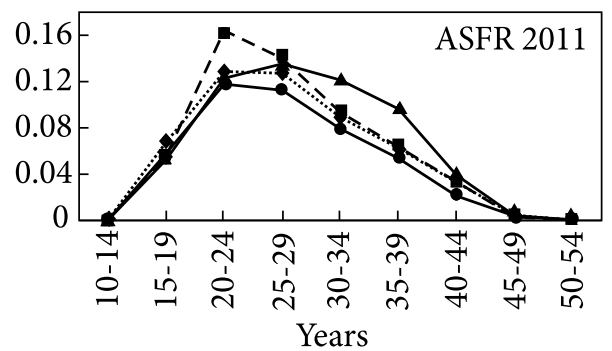

ASFR Kwazulu-Natal 2011

ASFR Mpumalanga 2011

ASFR North West 2011

$\_$ASFR Limpopo 2011

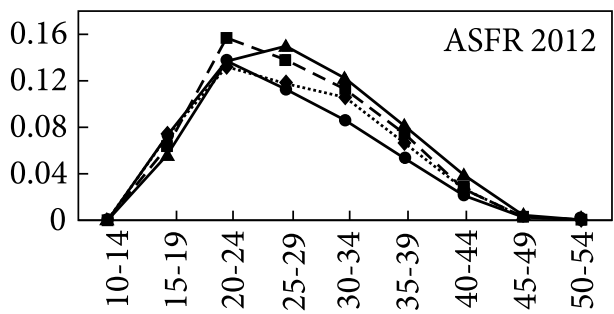

Years

$\rightarrow$ ASFR Kwazulu-Natal 2012

ASFR Mpumalanga 2012

- - ASFR North West 2012

$\_$ASFR Limpopo 2012

Fig. 1. Age-specific fertility rate in 2011 for all

Source: Authors, using General Household data, 2011-2014.

Fig. 2. Age-specific fertility rate in 2012 for all four provinces

Source: Authors, using General Household data, 2011-2014.
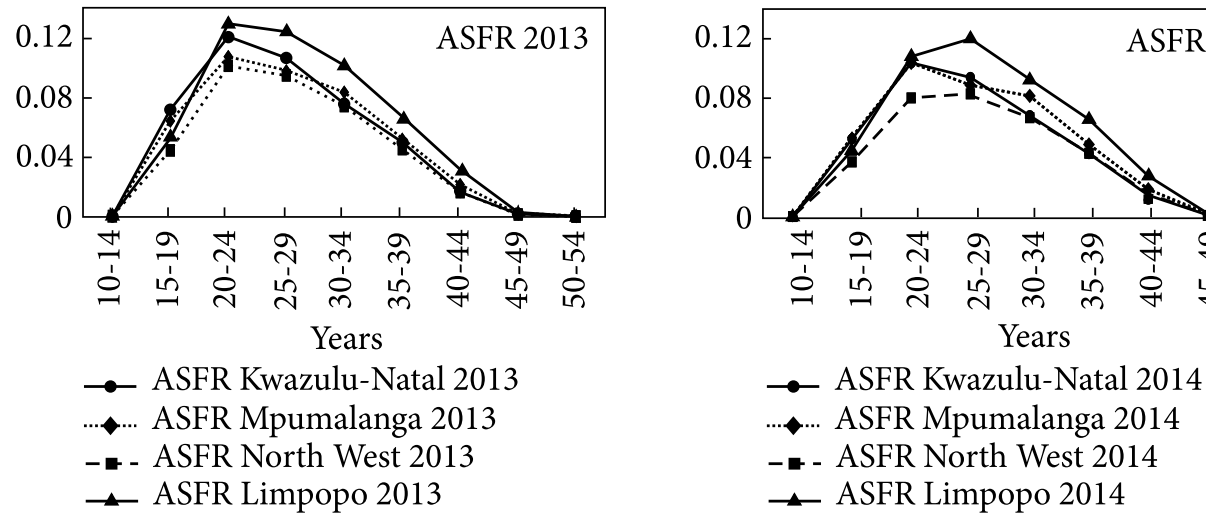

Fig. 3. Age-specific fertility rate in 2013 for all four provinces Source: Authors, using General Household data, 2011-2014.

Fig. 4. Age-specific fertility rate in 2014 for all four provinces Source: Authors, using General Household data, 2011-2014.
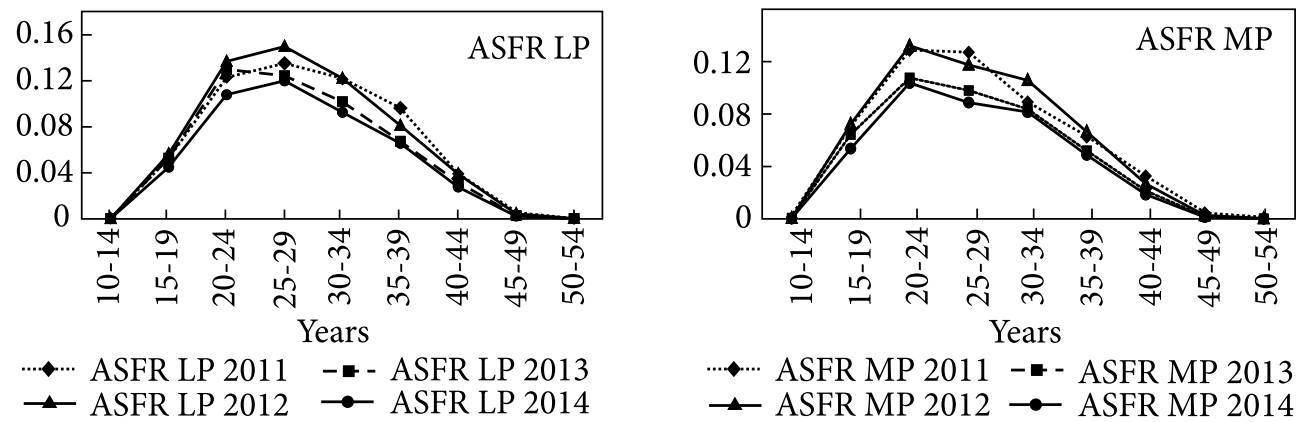

Fig. 5. Age-specific fertility rate in Limpopo for the years 2011-2014 Source: Authors, using General Household data, 2011-2014.

Fig. 6. Age-specific fertility rate in Mpumalanga for the years 2011-2014

Source: Authors, using General Household data, 2011-2014. 
Table 3. Age specific fertility rate for Limpopo Province

\begin{tabular}{|l|c|c|c|c|}
\hline \multicolumn{1}{|c|}{ AGE GROUPS } & ASFR LP 2011 & ASFR LP 2012 & ASFR LP 2013 & ASFR LP 2014 \\
\hline 10-14 years & 0.000409 & 0.000199 & 0.000386 & 0.00032 \\
$15-19$ years & 0.052479 & 0.056396 & 0.052759 & 0.044927 \\
20-24 years & 0.122915 & 0.136876 & 0.129997 & 0.107973 \\
$25-29$ years & 0.135301 & 0.14987 & 0.124465 & 0.120045 \\
30-34 years & 0.121364 & 0.122175 & 0.101854 & 0.092653 \\
35-39 years & 0.096444 & 0.081243 & 0.06748 & 0.06567 \\
$40-44$ years & 0.039249 & 0.03908 & 0.031749 & 0.027609 \\
$45-49$ years & 0.004145 & 0.004401 & 0.00298 & 0.002375 \\
50-54 years & 0.0002 & 0.000328 & 0.000238 & $9.18 \mathrm{E}-05$ \\
Total fertility rate & $\mathbf{2 . 8 6}$ & $\mathbf{2 . 9 5}$ & $\mathbf{2 . 5 6}$ & $\mathbf{2 . 3 1}$ \\
\hline
\end{tabular}

Source: Authors, using General Household data, 2011-2014.

Table 4. Age specific fertility rate for Mpumalanga Province

\begin{tabular}{|l|c|c|c|c|}
\hline \multicolumn{1}{|c|}{ AGE GROUPS } & ASFR MP 2011 & ASFR MP 2012 & ASFR MP 2013 & ASFR MP 2014 \\
\hline 10-14 years & 0.000561 & 0.000621 & 0.0007 & 0.000376 \\
15-19 years & 0.067538 & 0.072418 & 0.064422 & 0.053651 \\
20-24 years & 0.12876 & 0.132104 & 0.107624 & 0.103706 \\
$25-29$ years & 0.127195 & 0.117547 & 0.098044 & 0.088749 \\
30-34 years & 0.08919 & 0.105794 & 0.083737 & 0.081494 \\
35-39 years & 0.06245 & 0.066555 & 0.052103 & 0.048816 \\
$40-44$ years & 0.032794 & 0.026878 & 0.021551 & 0.018626 \\
$45-49$ years & 0.004588 & 0.002769 & 0.00197 & 0.001448 \\
50-54 years & 0.000401 & 0.000367 & 0.000209 & 0.000225 \\
Total fertility rate & $\mathbf{2 . 5 7}$ & $\mathbf{2 . 6 3}$ & $\mathbf{2 . 1 5}$ & $\mathbf{1 . 9 9}$ \\
\hline
\end{tabular}

Source: Authors, using General Household data, 2011-2014.

Table 5. Age-specific fertility rate for Kwazulu-Natal province

\begin{tabular}{|l|c|c|c|c|}
\hline \multicolumn{1}{|c|}{ AGE GROUPS } & $\begin{array}{c}\text { ASFR Kwazulu- } \\
\text { natal 2011 }\end{array}$ & $\begin{array}{c}\text { ASFR Kwazulu- } \\
\text { natal 2012 }\end{array}$ & $\begin{array}{c}\text { ASFR Kwazulu- } \\
\text { natal 2013 }\end{array}$ & $\begin{array}{c}\text { ASFR Kwazulu- } \\
\text { natal 2014 }\end{array}$ \\
\hline 10-14 years & 0.000379 & 0.000292 & 0.000378 & 0.000221 \\
15-19 years & 0.057909 & 0.073015 & 0.072095 & 0.052459 \\
20-24 years & 0.117775 & 0.137195 & 0.121223 & 0.103772 \\
25-29 years & 0.112455 & 0.112656 & 0.106944 & 0.093985 \\
30-34 years & 0.079108 & 0.085996 & 0.076158 & 0.068295 \\
35-39 years & 0.053708 & 0.053307 & 0.050339 & 0.042562 \\
40-44 years & 0.02114 & 0.021351 & 0.016662 & 0.014632 \\
45-49 years & 0.003787 & 0.002725 & 0.001903 & 0.001336 \\
50-54 years & 0.000663 & 0.00041 & 0.000436 & 0.000137 \\
Total fertility rate & $\mathbf{2 . 2 3}$ & $\mathbf{2 . 4 3}$ & $\mathbf{2 . 2 3}$ & $\mathbf{1 . 8 9}$ \\
\hline
\end{tabular}

Source: Authors, using General Household data, 2011-2014. 


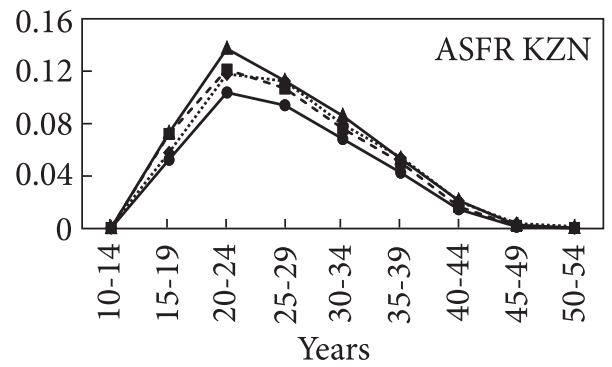

ASFR Kwazulu-Natal 2011

$\_$ASFR Kwazulu-Natal 2012

- - ASFR Kwazulu-Natal 2013

$\rightarrow$ ASFR Kwazulu-Natal 2014

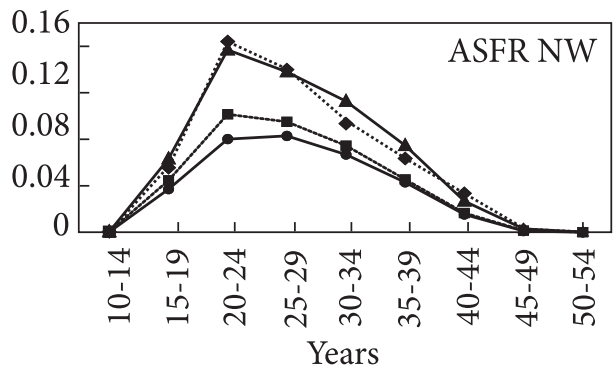

ASFR North West 2011

$\neg$ ASFR North West 2012

- - ASFR North West 2013

$\rightarrow$ ASFR North West 2014

Fig. 7. Age-specific fertility rate in Kwazulu-Natal for the years 2011-2014

Source: Authors, using General Household data, 2011-2014.

Fig. 8: Age-specific fertility rate in North West Province for the years 2011-2014 Source: Authors, using General Household data, 2011-2014.

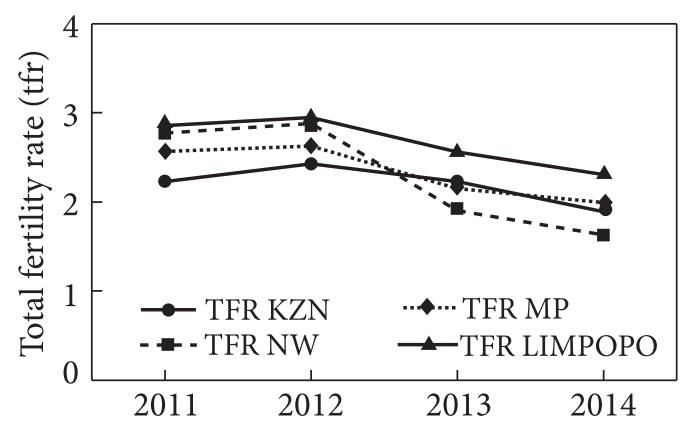

Fig. 9. Trend of Total Fertility Rate from 2011 to 2014, by Province

Source: Authors, using General Household data, 2011-2014.

Table 6. Age-specific fertility rate for North West Province

\begin{tabular}{|l|c|c|c|c|}
\hline \multicolumn{1}{|c|}{ AGE GROUPS } & $\begin{array}{c}\text { ASFR North } \\
\text { West 2011 }\end{array}$ & $\begin{array}{c}\text { ASFR North } \\
\text { West 2012 }\end{array}$ & $\begin{array}{c}\text { ASFR North } \\
\text { West 2013 }\end{array}$ & $\begin{array}{c}\text { ASFR North } \\
\text { West 2014 }\end{array}$ \\
\hline 10-14 years & 0.000404 & 0.000492 & 0.00048 & 0.000278 \\
15-19 years & 0.055571 & 0.06319 & 0.044677 & 0.037101 \\
$20-24$ years & 0.164107 & 0.156918 & 0.101518 & 0.08017 \\
$25-29$ years & 0.140005 & 0.138063 & 0.095053 & 0.082885 \\
30-34 years & 0.093523 & 0.112655 & 0.074477 & 0.066868 \\
35-39 years & 0.063497 & 0.074582 & 0.045424 & 0.042924 \\
$40-44$ years & 0.033471 & 0.02679 & 0.016571 & 0.015308 \\
$45-49$ years & 0.003081 & 0.002972 & 0.001443 & 0.001045 \\
50-54 years & 0.00016 & 0.000203 & 0.000136 & $2.2 \mathrm{E}-05$ \\
Total fertility rate & $\mathbf{2 . 7 7}$ & $\mathbf{2 . 8 8}$ & $\mathbf{1 . 9 0}$ & $\mathbf{1 . 6 3}$ \\
\hline
\end{tabular}

Source: Authors, using General Household data, 2011-2014. 
What caused the drop in fertility is a matter of great interest and needs to be investigated, especially in the case of the North West, where fertility drop was very important and steep. Generally, the fertility level in Limpopo is higher than all the others, and even though it is decreasing, it is still the highest among the four provinces. As mentioned above, fertility decline comes about from different ways and means for different countries or nations. The decrease in fertility in this case could be attributed to the level of education, which is rising. For the past five years, for example, the pass rate of the secondary school leaving examinations (known as matric in South Africa) has been increasing; and North West and Free State, for example, have scored over 10 percentage points increase in the pass rate (Minister of Basic Education, January 2018).

Limpopo is noted as the province with highest fertility in the whole of South Africa, which could be due to its rural nature (Kyei, 2011). But comparing the fertility rate of Limpopo in 2014 to the rates in the rest of Africa, it can be said that South Africa's fertility is the lowest or one of the lowest on the continent. In 2015, the fertility rate in Africa ranged from 2.27 in Cape Verde (the lowest) to 6.32 in Mali (the highest) (www.cnbcafrica.com). This study shows that South Africa's fertility in 2014 is about 2.7 while the rest of Africa is pegged at 4.5, and Asia is at 2.1; Latin America at 2.0; North America at 1.9 and Europe at 1.6 (www.cnbcafrica.com.)

The GRR for all the provinces were greater than one in 2011 and 2012, indicating that the population was growing because the women were more than replacing themselves with daughters. However, in 2013, the GRR for North West fell below replacement level; and in fact in 2014, except Limpopo the GRR for the other three provinces fell below the replacement level. This implies that the fertility of the black population of the country has gone down steadily, and the reason for the decline could be due to social and economic improvement that the black population is experiencing now. And if the fertility decline is not checked, South African population will dwindle below the replacement level. Already, the White population in South Africa had reached a fertility rate which was far below the replacement level and is still decreasing (Moultrie and Timaeus, 2002; Udjo, 2009).

Conclusion. This study has shown that the Household Survey data are fairly reliable with age ratio score hovering around five. Fertility level is going down below replacement level implying that the fertility of the black population is also dropping fast. The reason for which the fertility level is going down is not easy to pinpoint, as said earlier, but rising educational standard, social and health development, including access to medical and health facilities could play some role. Limpopo's fertility is the highest in the country, but comparing its rate with the rates from the countries on the continent, South Africa is becoming the country with the lowest fertility. In 2014, except Limpopo, the fertility rates in all the provinces have dropped below replacement level. 
The fact that the fertility levels are going below replacement levels (GRR below one in three provinces in 2014) should be a concern for policy makers because leaving such levels unchecked could lead to the loss of manpower in the labour market as it is seen in highly developed countries such as Canada, Japan, France and Nordic countries, and some of them are now depending on immigrants to boost manpower level in the labour market. This study therefore advises or even warns that policy makers in South Africa take note and act swiftly to avert population "extinction".

\section{REFERENCES}

1. Assefa and Semahegn Fertility Research and Practice (2016). Fertility is below replacement in Harar Health and Demographic Surveillance System (Harar HDSS), Harar town, Eastern Ethiopia.

2. Bhat, M., \& Zavier, F. (2003). Fertility decline and gender bias in Northern India. Demography, 40 (4).

3. Caldwell, J. C., \& Caldwell, P. (2003). The fertility transition in sub-Saharan Africa, In Fertility: the current South African issues (HSRC Department of Social Development).

4. Caldwell, J. C., \& Caldwell, P. (1993). The South African fertility decline. Population and development review, 19 (2).

5. Clark, S. (2000). "Son Preference and Sex Composition of Children: Evidence from India." Demography, 37: 95-107.

6. Kyei, K. A. (2007). Vital Registration System in Africa. A review of priorities. Paper presented at National Population Conference in Mafeking. North West, July 2007.

7. Kyei, K. A. (2011). Comparison of the Historical Fertility Levels among the Nine Provinces of South Africa. Journal of Human Ecology, 35 (2): 85-94.

8. Rossouw L., Burger, R. \& Burger, R. (2012). The fertility transition in South Africa: A retrospective panel data analysis, Stellenbosch Economic Working Papers: 03/12 March 2012.

9. Limpopo City Guide. Internet, Southern Africa places.co.za accessed on 20 October 2016.

10. Moultrie, T. A., \& Timaeus, I. M. (2002). Trends in South African Fertility between 1970 and 1998: An Analysis of the 1996 Census and the 1998. Demographic and Health Survey, http://www.mrc.ac.za/bod/trends.pdf.

11. Dorrington, R., Timaeus, Ian M., Moultrie, T., \& Nannan, N. Estimates of provincial fertility and mortality in South Africa; 1985-1996.

12. Statistics South Africa (2012). Statssa.gov.za/Publications/Reports -03-01-67/Report -0301-672011

13. Swartz, L. (2002). Fertility Transition in South Africa and its implications on the four major population groups, Expert Group meeting on Completing the Fertility Transition, New York, UN Population Division Department of Economic and Social Affairs.

14. Udjo, E. O. (2005). Fertility levels, differentials and trends. In Zuberi, Sibanda and Udjo (eds). The Demography of South Africa. New York: Sharpe, Inc.

15. Udjo, E. O. (2009). Population estimates for South Africa by magisterial district and province, 2008, Bureau of Market Research (Pretoria: University of South Africa).

Article submitted on 10.11.2020. 
K. A. Кей, канд. наук (член факультету, реорганізована кафедра статистики)

Департамент статистики, Університет Венди

Приватна скринька Х5050, Тохойандоу, 0950, провінція Лімпопо, ПАР

E-mail: Kyei61@gmail.com; Kwabena.Kyei@univen.ac.za

ORCID: 0000-0003-1630-3906

P. С. Рамуя, канд. стат. наук (аспірант)

Департамент статистики, Університет Венди

Приватна скринька Х5050, Тохойандоу, 0950, провінція Лімпопо, ПАР

E-mail: Ramuyarotondwa@gmail.com

ORCID: 0000-0003-4404-2264

\section{ВИЗНАЧЕННЯ РІВНЯ ТА ТЕНДЕНЦІЙ НАРОДЖУВАНОСТІ У ЧОТИРЬОХ ПРОВІНЦІЯХ ПІВДЕННОЇ АФРИКИ}

Актуальність дослідження: вивчення народжуваності та смертності має велике значення, оскільки показує динаміку населення та необхідність ефективних заходів планування, що необхідно вжити для запобігання катастрофи. Тому для Південної Африки важливо також перевірити, чи їі народжуваність рухається до тієї траєкторії, яка спостерігається в розвинених країнах. Це дослідження має на меті визначити рівень та тенденцію народжуваності в Південній Африці, використовуючи чотири провінції: Мпумалангу, Квазулу-Натал, Північно-Західну та Лімпопо у 2011-2014 роках. Завдання дослідження: а) чи змінювався рівень народжуваності в провінціях упродовж 2011-2014 років; б) яка тенденція? в) чи народжуваність падає нижче рівня заміщення? Наукова новизна статті: проведене дослідження показує, що дійсно народжуваність у Південній Африці знизилась, оскільки в деяких провінціях рівень народжуваності нижче рівня заміщення. Зниження, яке спостерігається в цьому дослідженні, головним чином пов'язано з народжуваністю темношкірого населення. Високі темпи приросту населення були зумовлені в основному народжуваністю темношкірих, тому, коли нещодавні рівні народжуваності в країні були низькі, це означає, що народжуваність темношкірих знизилася. Про це насправді й свідчить дослідження, та наголошує на тому, що якщо не будуть вжиті дієві заходи, народжуваність темношкірих або народжуваність у Південній Африці знизиться нижче рівня заміщення. Рівень народжуваності знизився у всьому світі, включаючи Південну Африку. Але ступінь зниження народжуваності Південної Африки є не дуже зрозумілим, оскільки дані двох попередніх переписів населення щодо народжуваності та смертності були дуже бідними. Південно-Африканська Республіка мала достовірні дані про біле населення країни, але з новим розпорядженням з 1994 р. збір даних, особливо серед темношкірого населення, що становить більшість, непростий. Якість даних темношкірого населення, що становить понад 80 \% населення, не була хорошою та надійною ймовірно, через низький рівень освіти цього сегмента. Дані про народжуваність та смертність, отримані за результатами двох попередніх переписів, 2001 та 2011 рр., були недостовірними порівняно з даними статистики життєдіяльності та національного реєстру населення. Таким чином, оцінки даних указаних переписів щодо цих подій є сумнівними. Однак у Південній Африці є дані Загальних обстежень домогосподарств (GHS), і дослідження використовує дані цих опитувань, щоб спробувати визначити рівень та тенденцію народжуваності. GHS - це щорічне опитування домогосподарств, яке вимірює життєві обставини домогосподарств Південної Африки. Демографічні та статистичні методи були використані для розрахунку показників, як-от: співвідношення вікових показни- 
ків ООН, для оцінки якості даних з чотирьох провінцій, а саме: Північно-Західної, Квазулу-Натальської, Мпумаланзької та Лімпопоської за період з 2011 по 2014 рік. Чотири провінції були обрані як тематичне дослідження для порівняння характеристик народжуваності сільських та міських територій. Результати показують, що якість даних опитування $є$ досить хорошою та надійною, оскільки провінція Квазулу-Натал має найнадійніші дані. Рівень народжуваності був найнижчим у більш урбанізованих та освічених провінціях Квазулу-Натал та Північно-Західному регіоні, а найвищим у менш освічених та сільських провінціях Лімпопо та Мпумаланга. Далі дослідження показує, що народжуваність у всіх провінціях знижується з 2012 року, а рівень валового відтворення падає нижче рівня заміщення: це означає, що народжуваність темношкірого населення швидко падає. Зниження рівня народжуваності можна пояснити низкою факторів, включаючи освіту, урбанізацію та покращення первинної медичної допомоги. Через різке зниження рівня народжуваності в останні роки дослідження потребує належного втручання політичних сил, щоб уникнути вимирання населення.

Ключові слова: народжуваність, опитування домогосподарств, надійність, рівень заміни, тенденція. 